\title{
Unilateral central retinal artery occlusion as the sole presenting sign of Susac syndrome in a young man: case report
}

\author{
Oclusão unilateral da artéria central da retina como único sinal de apresentação da síndrome de Susac \\ em jovem do sexo masculino: relato de caso
}

Samira luiza dos Apóstolos-Pereira ${ }^{1}$, Lúcia B. Passos Kara-José², Paulo Euripedes Marchiori ${ }^{1}$, Mário Luiz Ribeiro Monteiro²

\begin{abstract}
We report the case of a 24-year-old man presenting with sudden visual loss in the left eye from a central retinal artery occlusion. An extensive clinical investigation revealed no etiology. Three weeks later, however, the patient developed hearing loss followed by encephalopathy and multiple branch retinal artery occlusions in the right eye. Fluorescein angiography confirmed retinal vascular occlusions with no sign of vasculitis. The neurological examination revealed a diffuse encephalopathy while the MRI scan disclosed several small areas of infarcts in the brain. Bilateral sensorineural hearing loss was confirmed on audiometry. The patient was diagnosed with Susac syndrome and treated with methylprednisolone and cyclophosphamide, resulting in slight improvement and stabilization. This case shows that Susac syndrome may be diagnosed late due to the absence at onset of one or more of the symptoms of the classic triad (encephalopathy, multiple branch retinal artery occlusions and hearing loss). This case also serves to emphasize that Susac syndrome should be considered in the differential diagnosis of central retinal artery occlusion, even in apparently healthy young men.
\end{abstract}

Keywords: Retinal artery occlusion; Susac syndrome/diagnosis; Susac syndrome/ drug therapy; Methylprednisolone/therapeutic use; Cyclophosphamide/therapeutic use; Hearing loss; Encephalopathy; Case report

\begin{abstract}
RESUMO
Descrevemos um paciente de 24 anos, sexo masculino, que se apresentou com perda súbita da visão do ol ho esquerdo causado por oclusão da artéria central da retina. Ele foisubmetido à investigação clínica detalhada sem encontraruma causa. Trêssemanas depois, no entanto, desenvolveu surdez, encefalopatia e múltiplas oclusões de ramo arterial da retina no olho direito. Angiofluoresceinografia confirmou as oclusões de ramo arterial no $O D$ e oclusão da artéria central da retina no $O E$, sem qualquer sinal de vascutile. O exame neurológico revelou encefalopatia difusa, enquanto que o estudo efetuado por ressonância nuclear magnética mostrou várias áreas deenfarte do cérebro e a audiometria demonstrou perda auditiva neurosensorial bilateral. A síndrome de Susac foi diagnosticada e tratamento com metilprednisolona e ciclofosfamida instituido com melhora discreta, seguida de estabilização clínica. Este caso é importante para chamar a atenção de que nem todos os três critérios diagnósticos (encefalopatia, oclusão de ramo arterial retiniano e surdez) para a síndrome de Susac precisam estar presentes de início, o que pode causar confusão diagnóstica. O diagnóstico deve portanto ser incluído no diferencial de oclusão da artéria central da retina mesmo quando ocorre em homem sem outros sintomas associados.
\end{abstract}

Descritores: Oclusão da artéria retiniana; Síndrome de Susac/diagnóstico; Síndrome de Susac/quimioterapia; Metilprednisolona/uso terapêutico; Ciclofosfamida/uso terapêutico; Perda auditiva; Encefalopatia; Relato de caso

\section{INTRODUCTION}

Susac syndrome (SS) is an arterial occlusive disease associated with a triad of symptoms: encephalopathy, hearing loss and multiple branch retinal artery occlusions (MBRAO) $)^{(1-3)}$. Other findings include diffuse neurological signs as headache, psychiatric disturbances, cognitive changes, memory loss, and confusion that may rapidly progress to dementia. Magnetic resonance imaging (MRI) shows a distinctive pattern of hyperintense white matter lesions (on T2 and FLAIR sequences) with preferential involvement of the central callosal fibers and the development of central callosal holes as the active lesions resolve ${ }^{(4)}$. SS is presumably autoimmune in origin and treatment is still uncertain, but steroids, cyclophosphamide, azathioprine, plasmapheresis and intravenous immunoglobulin have been used with some success to halt disease progression ${ }^{(4,5)}$.

Though rare, SS may be readily suspected in the presence of the classic triad of symptoms. However, one or more of these symptoms may be absent at onset, leading to diagnostic confusion. The purpose of this paper was to describe a case of SS presenting with the sole finding of unilateral central retinal artery occlusion (CRAO) and, consequently, to propose the inclusion of SS in the differential diagnosis of CRAO, particularly in young patients without other risk factors for arterial occlusive disease.

\section{CASE REPORT}

A 24-year-old Afro-Brazilian man developed sudden visual loss in the left eye (OS). The ophthalmologic examination revealed visual acuity of 20/20 in the right eye (OD) and finger counting in OS. A marked relative afferent papillary defect was observed in OS. Ophthalmoscopy was normal in OD but revealed a CRAO in OS ( $\mathrm{Fi}$ gure 1). The initial neurological and clinical findings were unremarkable. An investigation involving carotid duplex scan, trans-esophageal echocardiography, cranial computerized tomography scan, complete blood count and serum glucose level revealed no abnormalities. The patient was prescribed $100 \mathrm{mg}$ acetyl salicylic acid/day. 
Three weeks later the patient developed tinnitus and sudden right hearing and visual loss followed by headache, apathy, confusion and somnolence. A repeat neurological examination showed the patient to be torporous, with brisk reflexes, bilateral extensor plantar responses and pseudobulbar speech. Visual acuity was 20/100 in OD and finger counting in OS. The fundus examination revealed MBRAO involving the superonasal and the infero-temporal branches of the central retinal artery in OD (Figure 2) and a CRAO in OS. The MRI scan disclosed several small areas of hyperintense signal on T2-weighted images in the gray and white matter, including the involvement of the central fibers of the corpus callosum (Figure 3). A lumbar puncture revealed clear and colorless cerebro-spinal fluid with 9 cells (92\% lymphocytes) and a protein level of $126 \mathrm{mg} / \mathrm{dl}$. Retinal fluorescein angiography confirmed MBRAO in OD and a CRAO in OS.

The blood sedimentation rate and the levels of $C$ reactive protein, antinuclear antibodies, serum complement, IgG and IgM anticardiolipin antibodies and lupic anticoagulant were within normal ranges. SS was diagnosed and immunosuppressive therapy with intravenous methylprednisolone (1 g/day for 5 days) and cyclophosphamide was prescribed. The patient's mental status improved slightly over the

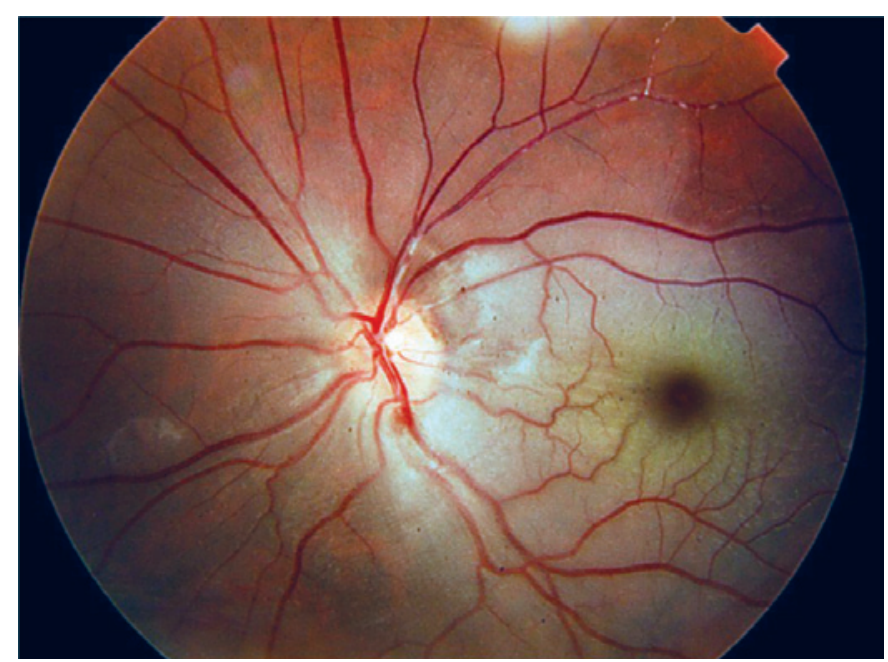

Figure 1. Fundus photograph of the left eye at presentantion showing central retinal artery occlusion.

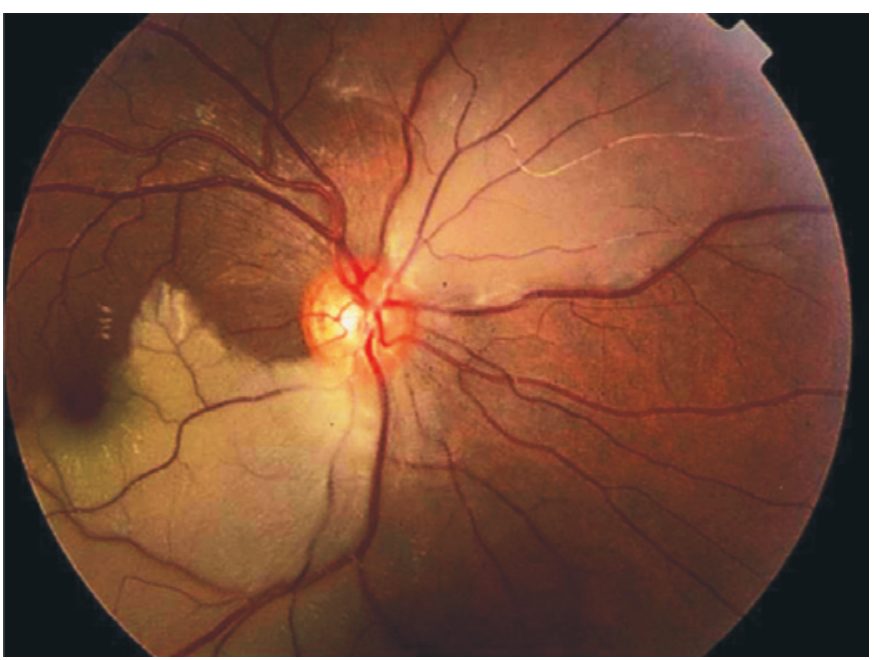

Figure 2. Fundus photograph of the right eye showing branch retinal artery occlusions in the regions superonasal and inferotemporal to the optic disc. following two months, followed by stabilization. Oral prednisone was prescribed at $60 \mathrm{mg} /$ day for two months, then tapered to $40 \mathrm{mg} /$ day for one month, then to $20 \mathrm{mg} /$ day. When tinnitus returned, the dose was raised to and maintained at $40 \mathrm{mg} /$ day. Six months later, the patient remained stable despite the persistence of visual field deficits, hearing deficit and tinnitus. Prednisone was tapered and discontinued. After 3 years of follow-up, the patient remains stable, with no recurrences.

\section{DISCUSSION}

When confronted with a patient with CRAO, most authors recommend routine screening for possible sources of emboli, especially the cardiac valves and the carotid artery ${ }^{(6,7)}$. Once embolism is ruled out, conditions such as vasculitis and coagulation disorders should be considered, particularly in young adults. Our case is interesting in that our SS patient presented initially with only one symptom: unilateral isolated CRAO. Despite careful investigation, no cause was found. However, three weeks later MRAO developed in the contralateral eye associated with headache, hearing loss and encephalopathy. The manifestation of these additional symptoms allowed to diagnose the patient with SS.

Susac syndrome was first described in 1979 by Susac and coworkers as a microangiopathy of the brain and retina(1). In two subsequent papers, SS was defined as a microangiopathic syndrome of arterial occlusive disease leading to the classic triad of encephalopathy, hearing loss and MBRAO(2,3) The pathogenesis of SS remains unknown, but presumably an autoimmune process leads to
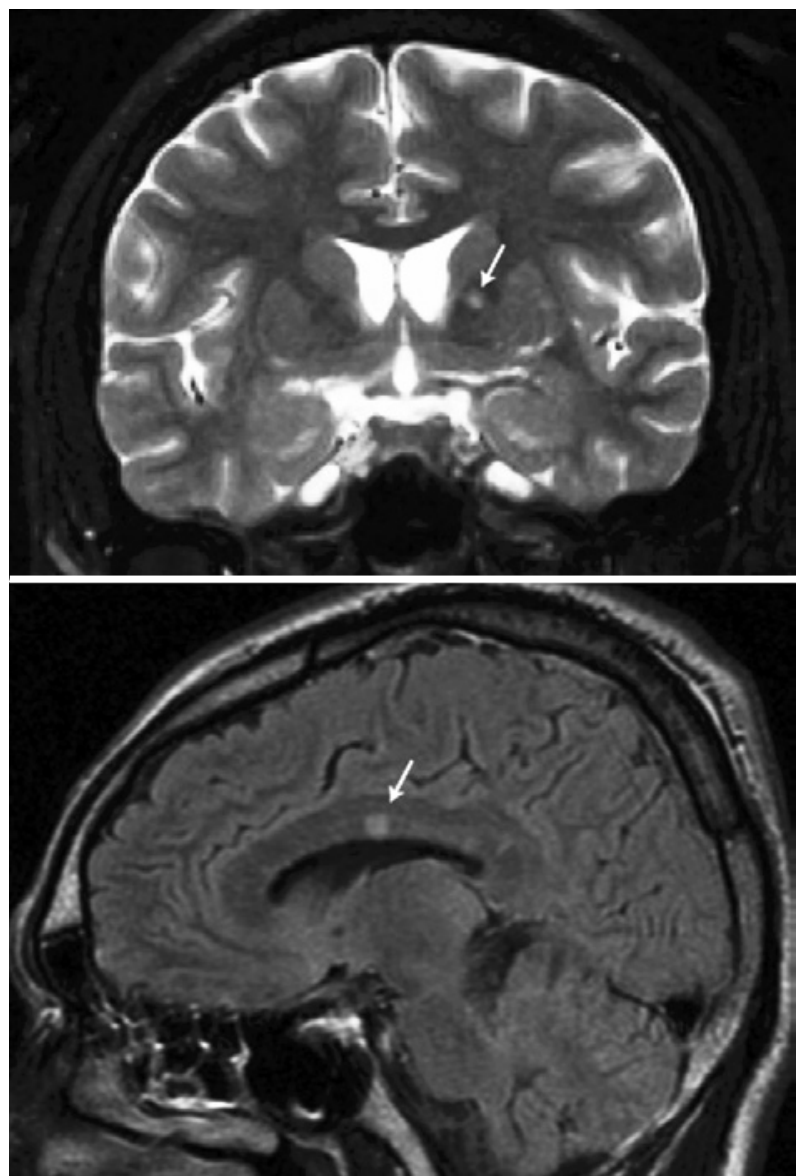

Figure 3. Magnetic resonance imaging showing hyperintense lesions (arrows) in the white matter (above) and in the central fibers of the corpus callosum (below). 
damage and inflammation-related occlusion of the microvessels in the brain, retina, and inner ear ${ }^{(5)}$. Because the first 20 cases reported were women aged 21-41 years, the syndrome was initially believed to affect only young females. Later, however, the condition was shown to occur in males as well, but with a female preponderance of approximately 3 to $1^{(5,8)}$. The diagnosis is based primarily on the clinical presentation, the documentation of MBRAO by fluorescence angiography, and characteristic findings on cerebral MRI. A variety of differential diagnoses have to be considered, including multiple sclerosis, acute disseminated encephalomyelitis, vasculitis of the central nervous system, infectious encephalitis, Menière's disease and Cogan syndrome ${ }^{(5)}$.

Only one previous case of SS presenting with CRAO has been reported. Adatia and Sheidow ${ }^{(9)}$ reported the case of a 36-year-old woman with slurred speech, decreased hearing, paresthesia, weakness and acute visual loss in OS due to CRAO. Despite the associated neurological symptoms, the diagnosis of SS was not made until one month later when MBRAO developed in the contralateral eye ${ }^{(9)}$. Permanent morbidity appears to be more severe when the diagnosis of $\mathrm{SS}$ is delayed. Thus, a high level of suspicion is recommended. The case reported here adds to the spectrum of the disease and shows that CRAO can be the sole presenting sign of SS, even in young and apparently healthy men.

\section{REFERENCES}

1. Susac JO, Hardman JM, Selhorst JB. Microangiopathy of the brain and retina. Neurology.1979;29(3):313-6.

2. Monteiro ML, Swanson RA, Coppeto JR, Cuneo RA, DeArmond SJ, Prusiner SB. A microangiopathic syndrome of encephalopathy, hearing loss, and retinal arteriolar occlusions. Neurology.1985;35(8):1113-21.

3. Coppeto JR, Currie JN, Monteiro ML, Lessell S. A syndrome of arterial-occlusive retinopathy and encephalopathy. Am J Ophthalmol. 1984;98(2):189-202.

4. Susac JO, Egan RA, Rennebohm RM, Lubow M. Susac's syndrome: 1975-2005 microangiopathy/autoimmune endotheliopathy. J Neurol Sci. 2007;257(1-2):270-2.

5. Kleffner I, Duning T, Lohmann $\mathrm{H}$, et al. A brief review of Susac syndrome. J Neurol Sci. 2012;322(1-2):35-40.

6. Graham EM. The investigation of patients with retinal vascular occlusion. Eye (Lond) 1990;4 (Pt 3):464-8.

7. Sharma S, Naqvi A, Sharma SM, Cruess AF, Brown GC. Transthoracic echocardiographic findings in patients with acute retinal arterial obstruction. A retrospective review. Retinal Emboli of Cardiac Origin Group. Arch Ophthalmol. 1996;114(10):1189-92.

8. Gross M, Banin E, Eliashar R, Ben-Hur T. Susac syndrome. Otol Neurotol 2004;25(4): 470-3.

9. Adatia FA, Sheidow TG. Central retinal artery occlusion as the initial ophthalmic presentation of Susac's syndrome. Can J Ophthalmol. 2004;39(3):288-91. 